\title{
A REASSESSMENT OF THE PTERAICHNUS ICHNOSPECIES FROM THE EARLY CRETACEOUS OF SORIA PROVINCE, SPAIN
}

\author{
BÁRBARA SÁNCHEZ-HERNÁNDEZ, ANDREW G. PRZEWIESLIK, and MICHAEL J. BENTON* \\ University of Bristol, Department of Earth Sciences, Wills Memorial Building, Queens Road, \\ Bristol BS8 1RJ, U.K., Mike.Benton@bristol.ac.uk
}

\begin{abstract}
The Cameros Basin, distributed over Soria, La Rioja and Burgos provinces in NE Spain, is apparently one of the richest sources of pterosaur footprints, with six ichnospecies of Pteraichnus named to date. The Cameros Basin exposes $9 \mathrm{~km}$ thickness of Late Jurassic and Lower Cretaceous continental deposits that are richly fossiliferous. Of the six alloformations in this sequence, the Huérteles Alloformation is a succession of alluvial siliclastics and lacustrine limestones dated as Tithonian-Berriasian in age. The pterosaur footprints are described, and compared with related forms from elsewhere. Of the six ichnospecies named from the Cameros Basin, Pteraichnus palacieisaenzi and P. cidacoi are nomina dubia because they lack holotypes housed in a public institution. Further, $P$. manueli and $P$. vetustior cannot be characterized at present, and so are also regarded as nomina dubia until diagnostic characters may be identified. $P$. longipodus and $P$. parvus are probably valid taxa, distinct from $P$. saltwashensis and $P$. stokesi, named previously from North America. Of the four supposed pterosaurian ichnogenera, Pteraichnus is valid, and Purbeckopus and Haenamichnus may be valid, but Agadirichnus is a nomen dubium because it is poorly characterized and lacks type specimens.
\end{abstract}

\section{INTRODUCTION}

Pterosaur tracks have attracted considerable attention in the debate over pterosaurian locomotion, whether these ancient flying reptiles walked bipedally and more or less upright like little dinosaurs (Padian 1983) or moved in a clumsier way, with their hindlegs splayed and their hands touching the ground in a quadrupedal stance (Lockley et al. 1995; Bennett, 1997; Unwin 1997). The debate over the posture and mode of life of pterosaurs has stimulated renewed interest in pterosaur tracks, with descriptions of new locations and new ichnotaxa from many parts of the world, including spectacular new examples from Poland (Pienkowski and Niedzwiedzki, 2005), France (Billon-Bruyat and Mazin, 2003) and Spain (e.g., Meijide Calvo 2001; Meijide Calvo and Fuentes Vidarte, 2001; Fuentes Vidarte et al., 2004a, b). Most of these examples have been assigned to the ichnogenus Pteraichnus, and the assumption has been that all such trackways are indeed pterosaurian, although Padian and Olsen (1984) and Padian (2003) have made a spirited case that the original Pteraichnus, and many others, were made by crocodilians.

Three ichnogenera of purported pterosaur tracks have been described: Pteraichnus Stokes, 1957, Purbeckopus Delair, 1963 and Haenamichnus Hwang et al., 2002. A further possible pterosaur ichnogenus, Agadirichnus Ambroggi and Lapparent, 1954, was named before Pteraichnus and might have date priority (but see below). Up to 2000, there were two ichnospecies of Pteraichnus, P. saltwashensis Stokes, 1957 and P. stokesi Lockley et al., 1995, but in 2000 and 2001, five new ichnospecies of Pteraichnus were described from the Berriasian deposits of Spain: Pteraichnus palaciei-saenzi Pascual Arribas and Sanz Pérez, 2000, $P$. vetustior Meijide Fuentes, 2001, P. manueli Meijide Calvo, 2001, P. cidacoi Fuentes Vidarte, 2001 and P. parvus Meijide Calvo et al., 2001. Without seeing the original material, BillonBruyat and Mazin (2003) reviewed the Spanish ichnospecies brief-

\footnotetext{
*Corresponding author.
}

ly and suggested that they were all nomina dubia. The original authors sought to refute this view, validating three of their five ichnospecies (Fuentes Vidarte et al., 2004a), and adding a new one, P. longipodus Fuentes Vidarte et al., 2004b. These six Spanish ichnospecies must be restudied and their validity reassessed with respect to all named purported pterosaurian ichnotaxa.

We have visited numerous outcrops where the Cameros Basin pterosaur tracks are visible in situ, and in 2005 and 2006 we examined the type materials of the new ichnospecies in the Museo Numantino, Soria. Our aim was to describe the tracks, make comparisons with such tracks from elsewhere, and determine the validity of the various ichnotaxa.

Institutional Abbreviations-CNUPH, Chonnam National University, Kwangju, South Korea; DORCM, Dorset County Museum, Dorchester, Dorset, England; MNS, Museo Numantino, Soria city (Castilla y León region, Soria Province, Spain); OUM, Oxford University Museum of Natural History, Oxford, England; UW, University of Wyoming, Laramie.

\section{GEOLOGICAL SETTING}

All the ichnospecies of Pteraichnus analyzed herein are from the Huérteles Alloformation, a subdivision of the Oncala Group that spans the Tithonian-Berriasian (latest Jurassic and earliest Cretaceous) interval in the Cameros Basin. The term 'Alloformation' is generally used in descriptions of these Spanish successions; it is the fundamental unit in allostratigraphy, defined by bounding unconformities (Bossi, 1998). The Cameros Basin is a pull-apart basin situated over Paleozoic basement rocks, and active during the Late Jurassic to Late Cretaceous. It can be divided into a western and eastern sub-basin. In the eastern Cameros basin, around the outcrop (Fig. 1), the maximum thickness of sediment is $9000 \mathrm{~m}$. The Huérteles Alloformation consists of alluvial siliclastics and lacustrine limestones (Mas et al., 1993; Martín-Closas and Alonso Millán, 1998).

Because of intense deformation during the Alpine Orogeny, the sediments in the Cameros Basin have poor lateral continuity, and dating and correlation are difficult because of the absence of 


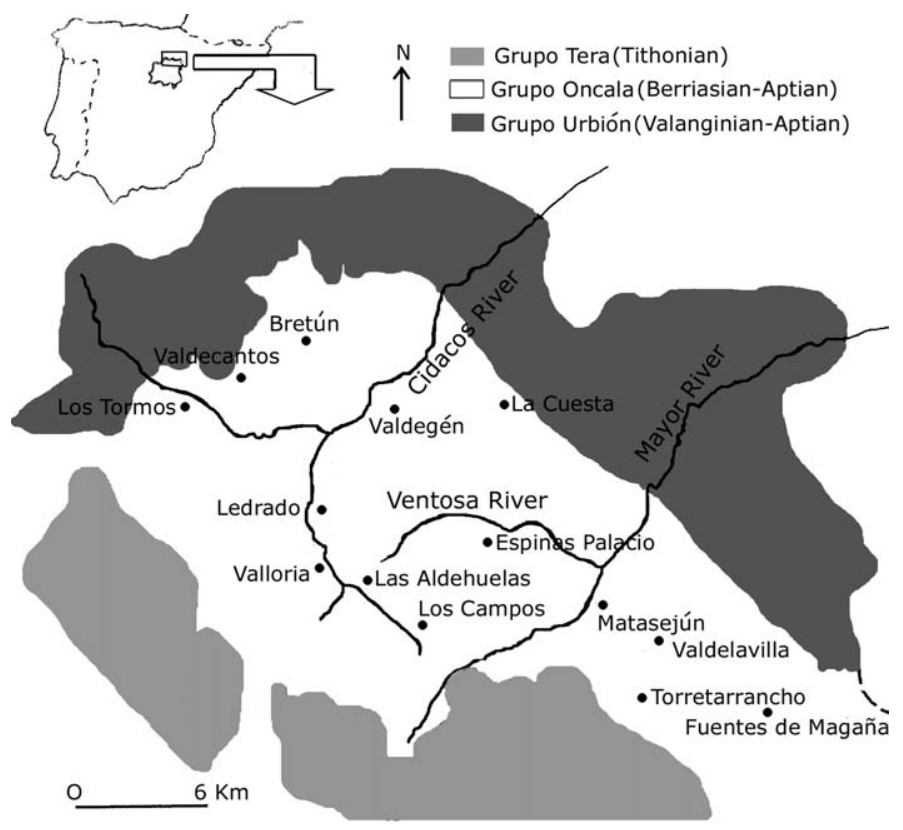

FIGURE 1. Geological setting of the northern part of the Cameros Basin in Soria Province. The marked area shows the outcrop of the Oncala Group (Berriasian-Aptian) in white, with pterosaur footprint localities marked by black spots, and named. The Urbion Group (Valanginian-Aptian) is shown in dark gray to the north of the basin, and the Tera Group (Tithonian) in paler gray to the south. (Modified from Pascual Arribas and Sanz Pérez, 2000).

index fossils (Tischer, 1965; Guiraud and Seguret, 1985; Mas et al., 1993; Gómez-Fernández and Meléndez, 1994a; Muñoz et al., 1997; Casas-Sainz and Gil, 1998; Martín-Closas and Alonso Millán, 1998). Table 1 presents a stratigraphic correlation scheme of the main sedimentary formations in the Cameros Basin.

The sediments of the Huérteles Alloformation (Fig. 2) are interpreted as the deposits of rivers flowing into a large lake located where Cornago is today (La Rioja Province). In the eastern part of the Cameros Basin, the environments were mainly saline lakes that received sediment from the NE (GómezFernández and Meléndez, 1994b). In the center of the basin there was a perennial saline lake that shows 10-meter cycles of lake filling and drying, with laminated limestones in their lower parts, and carbonate breccias at the top. Larger scale sedimentary cycles, some $300 \mathrm{~m}$ thick, indicate longer periods of climatic variation from a relatively humid to an arid climate. The lacustrine limestones and shales have produced diverse vertebrate tracks attributed to turtles, crocodilians, pterosaurs, and theropod, sauropod and ornithopod dinosaurs (Moratalla et al., 2003). Shells of the fresh-water bivalve Unio and Lepidotes-like teeth and scales are also common.

Slabs with Pteraichnus tracks are micritic muddy limestones and shales, and many bear mudcracks on the footprint surface. Some also bear branching burrows and trails made by invertebrates, as well as root traces, and isolated fish scales. Some slabs also bear ripple marks. These pieces of evidence confirm field observations that the pterosaur tracks were made on exposed shorelines of drying lakes close to the waterline.

\section{MATERIALS AND METHODS}

Field and Museum Methods-Several outcrops with pterosaur footprints from Soria Province were visited and many observations were made. So far, pterosaur tracks have been recorded from 16 localities in the Huérteles Alloformation of Soria Province, the best being Santa Cruz de Yanguas and Valdelavilla (also called 'Valdelalosa', by some authors). Los Tormos site is located approximately $3 \mathrm{~km}$ east of the Santa Cruz de Yanguas village and is a single outcrop that contains the holotype of Pteraichnus palaciesisaenzi (Pascual Arribas and Sanz Pérez, 2000), as well as tracks of Pteraichnus isp., and theropod dinosaur tracks at the same level. Ornithopod dinosaur tracks are on a younger layer. The Valdelavilla site, $5 \mathrm{~km}$ southeast of Matasejún, has yielded material of Pteraichnus cidacoi and P. vetustior (Fuentes Vidarte, 2004a; Meijide Fuentes, 2001). The outcrop area is extensive, and the $60-\mathrm{m}$ section contains eight track-bearing beds, dominated by Pteraichnus. Four of these horizons also contain dinosaur traces, notably Therangospodus oncalae, attributed to a large theropod, Archaeornithipus meijide, attributed to a bird, and unidentified ornithopod tracks (Fuentes Vidarte, 1996; Pascual Arribas and Sanz Pérez, 2000).

The holotypes, paratypes and all the pterosaur footprints housed in the MNS were measured using dial calipers. Several measurements were made on different days, and these were averaged, in order to ensure repeatability (Tables 2,3 ). The main parameters measured from the footprints are shown in Figure 3.

TABLE 1. The lithostratigraphic units and depositional sequences described from sectors of the Cameros Basin, based on Guiraud and Seguret (1985), Martín and Alonso (1998), and Martín-Closas and Alonso-Millán (1998).

Lithostratigraphic Units

\begin{tabular}{|c|c|c|c|c|}
\hline & & & & \\
\hline & & West Cameros & & \\
\hline U. Albian-Cenomanian & & Marine transgression & & Oliván Group \\
\hline M. Barremian & IV & Pantano de la Cuerda del Pozo Fm. & $\begin{array}{c}\text { Pantano de la Cuerda del } \\
\text { Pozo Fm. }\end{array}$ & $\begin{array}{l}\text { Pantano C. Pozo Fm./ } \\
\text { Cabretón Fm. }\end{array}$ \\
\hline $\begin{array}{l}\text { U. Hauterivian- } \\
\text { L. Barremian }\end{array}$ & III & $\begin{array}{l}\text { Hortigüela Formation/ Pinilla de los } \\
\text { Moros Fm. }\end{array}$ & Golmayo Fm. & Tera Formation/Cabretón Fm. \\
\hline Tithonian-Berriasian & I & $\begin{array}{l}\text { Campolara Fm./ Jaramillo de la } \\
\text { Fuente Fm. }\end{array}$ & - & Huérteles Fm. \\
\hline & & $\begin{array}{l}\text { Boleras Fm. } \\
\text { Ntra. Sra. De Brezales Fm. }\end{array}$ & $\begin{array}{l}\text { Hoya del Moro Fm. } \\
\text { Hoya del Moro Fm. }\end{array}$ & Magaña Fm. \\
\hline
\end{tabular}

The Huérteles Formation, source of the pterosaur tracks, is highlighted.

Abbreviations: D.S., depositional sequence; Fm., formation; L., lower; M., middle; U., upper. 


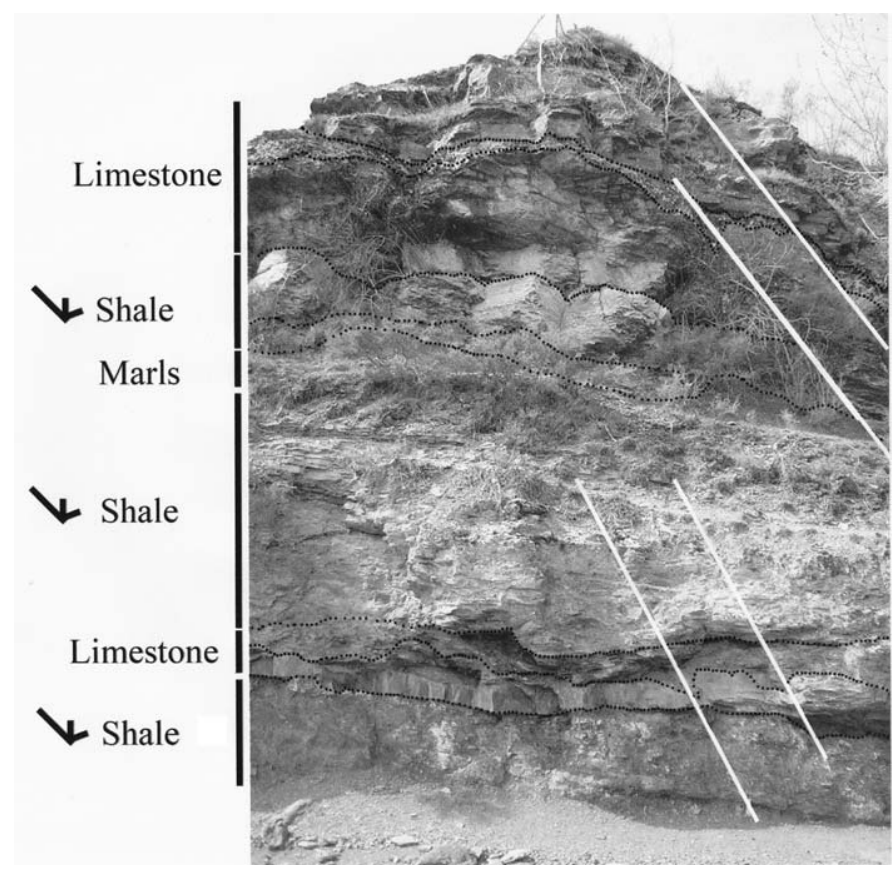

FIGURE 2. Section of the Huérteles Alloformation at the Los Tormos outcrop (Soria Province, Spain), with an indication of the pterosaur track-bearing beds (tridactyl marks). Dotted lines indicate unconformities and hard ground surfaces between the different lithologies. A set of faults is marked by diagonal white lines. The shale beds with pterosaur footprints at the Los Tormos outcrop are immediately beneath the section shown. The section is about $3 \mathrm{~m}$ high.

Latex molds were made from several of the type specimens to enable more detailed study and photography.

Principles of Ichnotaxonomy - In the taxonomic commentary on the named ichnotaxa, we follow the principles of the International Commission for Zoological Nomenclature (ICZN, 1999) in which ichnofossil names are treated like names for modern organisms or extinct organisms based on body fossils in terms of priority and validity: for taxa named after 1999, type material must be identifiable and lodged in a recognized institution (ICZN 1999, articles 16.4.1; 72.10). The name-bearing specimen should ideally show the diagnostic characters of the ichnotaxon, but need not. This means that, in the case of tetrapod tracks, a type specimens might be an isolated track, a manus or a pes imprint, rather than a whole trackway that should show several successive manus and pes imprints, so indicating stride length, pace angulation, and morphological variation resulting from preservational factors.

There has been a long-standing debate about the extent to which the inferred trackmaker can influence ichnotaxonomy. Many ichnofossil names - Arenicolites, Brontopodus, Iguanodonichnus, Pteraichnus - imply a trackmaker, and Billon-Bruyat and Mazin (2003) argue that this is an important issue. They argue that ichnotaxonomies should be integrated with skeletal taxonomies, and that ichnospecies, ichnogenera and ichnofamilies should match, as far as possible, such divisions of body fossil taxonomies. This then requires a composite approach, where decisions about naming ichnotaxa require information about the morphology and preservation of a trackway as well as reasoned inferences about who made the track. We reject this approach, and follow Bertling et al. (2006) in their recommendation, oft repeated before, that ichnofossil diagnoses should be based entirely on morphology, and that speculation about the track-maker should be a secondary, and unconnected, issue. Useful criteria for establishing unique ichnotaxon names, so-called ichnotaxobases (Bertling et al. 2006) include: morphology (overall shape, orientation, sculpture, internal structure) and composition, while size, taphonomy, postulated producer, sedimentological aspects, age, and location are rejected as potential diagnostic characters.

\section{SYSTEMATIC PALEONTOLOGY}

We review all ichnogenera and ichnospecies referred to pterosaurs, Ichnofamily Pteraichnidae, in chronological sequence of naming, but the intention is not to provide the final word on the systematics of all such tracks because we have not examined the non-Spanish material first-hand. The non-Spanish taxa are characterized briefly so that the Spanish ichnospecies may then be compared with pre-existing taxa. The Spanish taxa are considered in date order of their naming.

Ichnofamily PTERAICHNIDAE Lockley et al., 1995 Ichnogenus AGADIRICHNUS Ambroggi and Lapparent, 1954 (nomen dubium)

Ichnospecies AGADIRICHNUS ELEGANS Ambroggi and Lapparent, 1954 (nomen dubium)

Material-The holotype consists of two partial pedal imprints and an isolated, but not associated, manus imprint of poor quali-

TABLE 2. Key measurements of the named ichnospecies of pterosaur footprints, considered as valid ichnotaxa in this work.

\begin{tabular}{|c|c|c|c|c|c|c|c|}
\hline \multirow[b]{2}{*}{ Ichnotaxon } & \multirow[b]{2}{*}{ Key diagnostic characters } & \multirow[b]{2}{*}{ Digit length ratio manus } & \multirow[b]{2}{*}{ Length (mm) } & \multirow[b]{2}{*}{$\mathrm{L} / \mathrm{W}$} & \multicolumn{3}{|c|}{ I.A manus (degrees) } \\
\hline & & & & & I-II & II-III & I-III \\
\hline Pteraichnus saltwashensis & $\begin{array}{l}\text { Acuminate heel and straight toes; } \\
\text { manus longer than pes }\end{array}$ & $1: 2: 3$ to $1: 2: 4$ & $\begin{array}{l}90 \\
70\end{array}$ & $\begin{array}{l}2.6 \\
2.0-2.1\end{array}$ & $45-48$ & $42-45$ & 90 \\
\hline $\begin{array}{l}\text { Pteraichnus parvus } \\
\text { MNS2002/92/2 }\end{array}$ & $\begin{array}{l}\text { Small size, relatively short manus, } \\
\text { long sole and short digits }\end{array}$ & $1: 2: 4$ & $\begin{array}{l}25 \\
15\end{array}$ & $\begin{array}{l}2.0 \\
1.3\end{array}$ & 64 & 58 & 122 \\
\hline $\begin{array}{l}\text { Purbeckopus pentadactylus } \\
\text { DORCM G6664 }\end{array}$ & Large size of the pes imprint & $\mathrm{n} / \mathrm{a}$ & $\begin{array}{l}140 \\
200\end{array}$ & $\begin{array}{l}2.0 \\
1.9\end{array}$ & $\mathrm{n} / \mathrm{a}$ & $\mathrm{n} / \mathrm{a}$ & $\mathrm{n} / \mathrm{a}$ \\
\hline $\begin{array}{l}\text { Haenamichnus } \\
\text { uhangriensis CNUPH.P2 }\end{array}$ & $\begin{array}{l}\text { Extremely large size of manus and } \\
\text { pes; pes with trace of digit } 5\end{array}$ & $\mathrm{n} / \mathrm{a}$ & $\begin{array}{l}330 \\
350\end{array}$ & $\begin{array}{l}2.3 \\
2.4\end{array}$ & $\mathrm{n} / \mathrm{a}$ & $\mathrm{n} / \mathrm{a}$ & $\mathrm{n} / \mathrm{a}$ \\
\hline
\end{tabular}

Measurements of the manus and pes are given, with manus above and pes below for each ichnotaxon. All the values provided for the Spanish ichnospecies are from our own observations, P. stokesi values are from Lockley et al. (1995) and Bennett (1997), P. saltwashensis values are from Stokes (1957) and Lockley et al. (1995), Purbeckopus pentadactylus values are from Wright et al. (1997) and Haenamichnus from Hwang et al. (2002). See Figure 3 for indications of the key measurements. Abbreviations: I.A., interdigital angle; L, length; n/a, data not available; W, width. 
TABLE 3. Key measurements (in millimeters) of the holotypes of Pteraichnus manueli (MNS 2003/92/1), Pteraichnus parvus (MNS 2003/92/2), and Pteraichnus longipodus (MNS 2003/92/5).

\begin{tabular}{|c|c|c|c|c|c|c|}
\hline & \multicolumn{2}{|c|}{ P. manueli holotype } & \multicolumn{2}{|c|}{ P. parvus holotype } & \multicolumn{2}{|c|}{ P. longipodus holotype } \\
\hline & Manus & Pes & Manus & Pes & Manus & Pes \\
\hline Average length & 30.6 & 27.7 & 24.6 & 15.3 & 24.5 & 34.0 \\
\hline Average width & 8.2 & 10.5 & 12.0 & 11.4 & 16.7 & 17.4 \\
\hline Average length/Average width ratio & 3.7 & 2.2 & 2.0 & 1.3 & 1.5 & 2.0 \\
\hline Average length of digit I & 6.2 & 2.7 & 6.5 & 3.7 & 15.3 & 4.7 \\
\hline Average length of digit II & 16.6 & n.c. & 11.3 & 4.4 & 18.4 & 4.5 \\
\hline Average length of digit III & 27.6 & n.c. & 24.6 & 3.9 & 24.5 & 3.9 \\
\hline Average length of digit IV & n.a. & n.c. & n.a. & 3.46 & n.a. & 6.0 \\
\hline Number of measurements & 3 & 2 & 3 & 3 & 3 & 4 \\
\hline
\end{tabular}

Abbreviations: n.a., not applicable; n.c., not clear (damaged specimen).

ty. It is not stated whether the specimens were simply recorded in situ, or whether a specimen was lodged in a museum.

Locality-Within the Tagragra Anticline, between the rivers Laouar and Issene, approximately $12 \mathrm{~km}$ east of Agadir and 10 $\mathrm{km}$ north of Ait Melloui, Morocco.

Horizon-The Mesguina Bed, of Maastrichtian (latest Cretaceous) age.

Description-The pedal imprints are $105-115 \mathrm{~mm}$ long, tetradactyl, elongate and plantigrade, with slender digits. The pes shape is sub-triangular, with a rounded heel, and digits II and III are longer than I and IV. The manus imprint is poor, but is asymmetrical, elongate and tridactyl, with digits I and II tightly appressed.

Comments-Agadirichnus elegans could be the first-named pterosaurian track, as noted by Billon-Bruyat and Mazin (2003), but there are reasons for uncertainty. The only information is the paper by Ambroggi and Lapparent (1954), and the specimens have not been located. Agadirichnus has been assigned to lizards, birds, pterosaurs and mammals. Haubold (1971:52) followed the original authors in identifying the maker of the Agadirichnus pes tracks as 'saurian', that is, a lizard. Lockley and Foster (2003) suggested they might be mammalian tracks, and Billon-Bruyat and Mazin (2003) suggested they were made by pterosaurs. The latter authors identified some three-digit imprints that had been mentioned by Ambroggi and Lapparent (1954) as bird tracks as possible pterosaur manus imprints. Whatever the origin of these
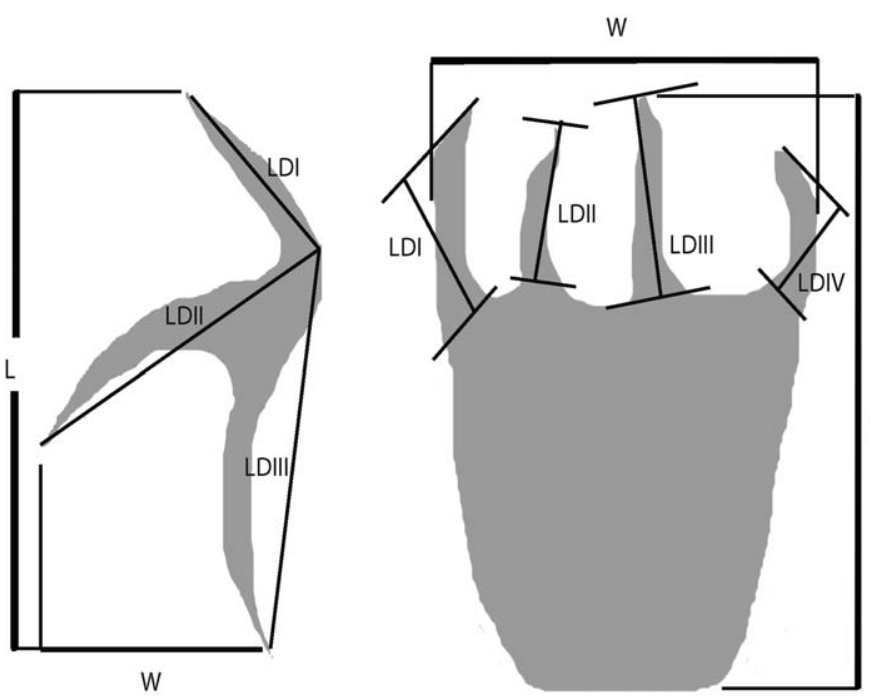

FIGURE 3. Principal parameters measured from Pteraichnus manus (left) and pes (right) tracks. Abbreviations: I.A., interdigital angle; I, II, III, digits I, II, III; L, length; LD: digit length; W, width. tracks, Agadirichnus should be regarded as a nomen dubium because there is no type specimen, and it is unclear whether the postulated manus imprints are associated with the pes imprints or not.

Ichnogenus PTERAICHNUS Stokes, 1957

Ichnospecies PTERAICHNUS SALTWASHENSIS Stokes, 1957

Material-Holotype is an unnumbered specimen mounted on display at the Geology Museum, University of Utah, a trackway of nine associated and consecutively alternating manus and pes imprints on four slabs.

Locality-Northwest flank of Carrizo Mountains, Apache County, Arizona, approximately 16.5 miles southwest of the Four Corners (Stokes, 1957).

Horizon-Middle of the Salt Wash Sandstone Member of the Morrison Formation. Late Jurassic (Kimmeridgian-Tithonian).

Description-A trackway consisting of alternating manus and pes prints. The manus print is about $90 \mathrm{~mm}$ long, tridactyl, asymmetrical, and digitigrade. All digits radiate from a central depression and they point posteriorly and laterally to the direction of travel. The anterior and middle digits bear traces of short ungual imprints that are rotated outward. Digit I and II imprints are short and point laterally, while the imprint of digit III is three times as long and points largely backwards with strong curvature. The pes prints are about $70 \mathrm{~mm}$ long, $\mathrm{V}$-shaped with an acutely-angled heel, plantigrade, functionally tetradactyl, symmetrical and with elongate digits that are subequal in length and may curve slightly at their distal ends. The manus and pes prints are equidistant from the midline of the trackway, and the pes prints may overprint or lie anterior to the ipsilateral manus imprints (Bennett, 1997). Manus imprints are often more deeply impressed than pes imprints (Lockley et al., 1995; Billon-Bruyat and Mazin, 2003)

Comments-Stokes (1957) numbered the three manus digit imprints as II, III and IV, but this was corrected to I, II and III by Bennett (1997) and others. Although disputed by Padian and Olsen (1984) and Padian (2003), most authors (Lockley et al., 1995; Bennett, 1997; Unwin, 1997; Billon-Bruyat and Mazin, 2003) have accepted that $P$. saltwashensis is a pterosaur trackway, probably of a pterodactyloid pterosaur because the fifth digit of the pes does not make contact with the ground. Basal 'rhamphorhynchoid' pterosaurs had a large fifth pes digit, whereas this toe is reduced in Pterodactyloidea.

\section{Ichnospecies PTERAICHNUS STOKESI Lockley et al., 1995}

Material-Holotype: six specimens and unnumbered latex peels housed in the Tate Geological Museum, Casper, Wyoming, under University of Wyoming numbers. Holotype is UW 12368, consisting of four associated sets of successive tracks. Further specimens are UW 12363, UW 12371 and UW 12372. 
Locality_Alcova Lake, Bighorn Basin, Wyoming.

Horizon-Sundance Formation. Middle to Upper Jurassic.

Description-The manus prints, about $70 \mathrm{~mm}$ long, are more deeply impressed than the pes prints. In the manus, the anterior digit is short and has a suboval imprint of a single digital pad and an imprint of an ungual, the middle digit has two digital pads with an imprint of an ungual, and the posterior digit shows a large elongate oval imprint that does not exhibit any clear division into separate digital pads. A single print in slab UW 12368 exhibits a faint imprint of a small pad distal to the large oval imprint and a clear imprint of the lateral aspect of a large and strongly curved claw. The pes is about $90 \mathrm{~mm}$ long, and the digits diverge moderately at roughly $30^{\circ}$ (lateral to medial digit divergence), but this varies. The pes is narrow with a rounded heel and sub-triangular shape. Most pes prints exhibit the imprints of a fifth digit along the lateral margin (Bennett, 1997).

Comments - Pteraichnus stokesi Lockley et al. (1995) was said to differ from $P$. saltwashensis in showing a greater degree of outward rotation of the pes with respect to the midline of the trackway, a pace angulation that is smaller by about $20^{\circ}$, a relatively shorter and wider third manual digit, and occasional traces of the fifth pes digit. Bennett (1997) and Billon-Bruyat and Mazin (2003) suggested that these differences were so slight as to be perhaps little more than a result of sharper preservation and a subtly different mode of locomotion. However, we believe the original diagnostic characters are valid, and note in addition that the proportional lengths of manus and pes differ: in $P$. saltwashensis the manus $(90 \mathrm{~mm})$ is longer than the pes $(70 \mathrm{~mm})$, whereas in P. stokesi the opposite is the case (manus $90 \mathrm{~mm}$; pes $70 \mathrm{~mm})$.

Ichnospecies PTERAICHNUS PALACIEISAENZI Pascual Arribas and Sanz Pérez, 2000 (nomen dubium)

Pteraichnus palaciei-saenzi Pascual Arribas and Sanz Pérez, 2000

Pteraichnus palacieisaenzi Pascual Arribas and Sanz Pérez, 2000 (Billon-Bruyat and Mazin, 2003)
Material-Holotype: manus print VDV-R3-7m and pes print VDV-R2-7p; Paratype: manus print VDV-R3-6m and pes print VDV-R4-1p. The four tracks are in situ at the Los Tormos outcrop, Santa Cruz de Yanguas, in different trackways, and the numbering system is based on Spanish terms $(\mathrm{R}$, rastros $=$ track; $\mathrm{m}$, mano $=$ manus $/$ hand; $\mathrm{p}$, pie = pes/ foot $)$.

Locality-Los Tormos outcrop, Santa Cruz de Yanguas, Soria Province, Spain (coordinates on geological map 280, Enciso, are 30T-WM453570).

Horizon-Sandy shales and sandstones of sub-unit IV-b of Huérteles Alloformation (Pascual Arribas and Sanz Pérez, 2000). Berriasian, Lower Cretaceous.

Description-According to Pascual Arribas and Sanz Pérez (2000), a trackway with average pace length of $66 \mathrm{~cm}$, stride length of $112 \mathrm{~cm}$, and pace angle of $92^{\circ}-135^{\circ}$. Manus print has average length of $107 \mathrm{~mm}$ and average width of $43 \mathrm{~mm}$. The ratio of lengths of digits I, II, and III is 1:2:4. Manual digit I is oriented anterolaterally and makes an angle of 80-85 degrees with the midline of the trackway (this angle is $130-135^{\circ}$ for digit II and $168-175^{\circ}$ for digit III). Pes print has average length of $147 \mathrm{~mm}$ and length/width ratio of 1.4. The toes had large nails and the metatarsal imprint extends for $3 / 7$ of the total length of the pes imprint. The two central toes are slightly longer than the other two and slightly diverging. Interdigital angle I-IV is $36^{\circ}$. Pes prints are oriented approximately $19^{\circ}$ from the midline of the trackway.

Comments-First, according to the ICZN Code (ICZN 1999; article 32.5.2.3), the original name $P$. palaciei-saenzi should be replaced by $P$. palacieisaenzi (Billon-Bruyat and Mazin, 2003). Further, the authors mistake two outcrops, indicating that the type materials are to be seen at the Barranco de Valdelavilla locality (their code VDV; Pascual Arribas and Sanz Pérez, 2000; fig. 22), although in fact they come from the Los Tormos outcrop, which they code as SCY (Pascual Arribas and Sanz Pérez, 2000: fig. 20; table 12). The preservation of the P. palacieisaenzi trackways from the Los Tormos outcrop is quite poor (Fig. 4).

Some of the features described by Pascual Arribas and Sanz Pérez (2000) as diagnostic for this ichnospecies apply to all Pter-
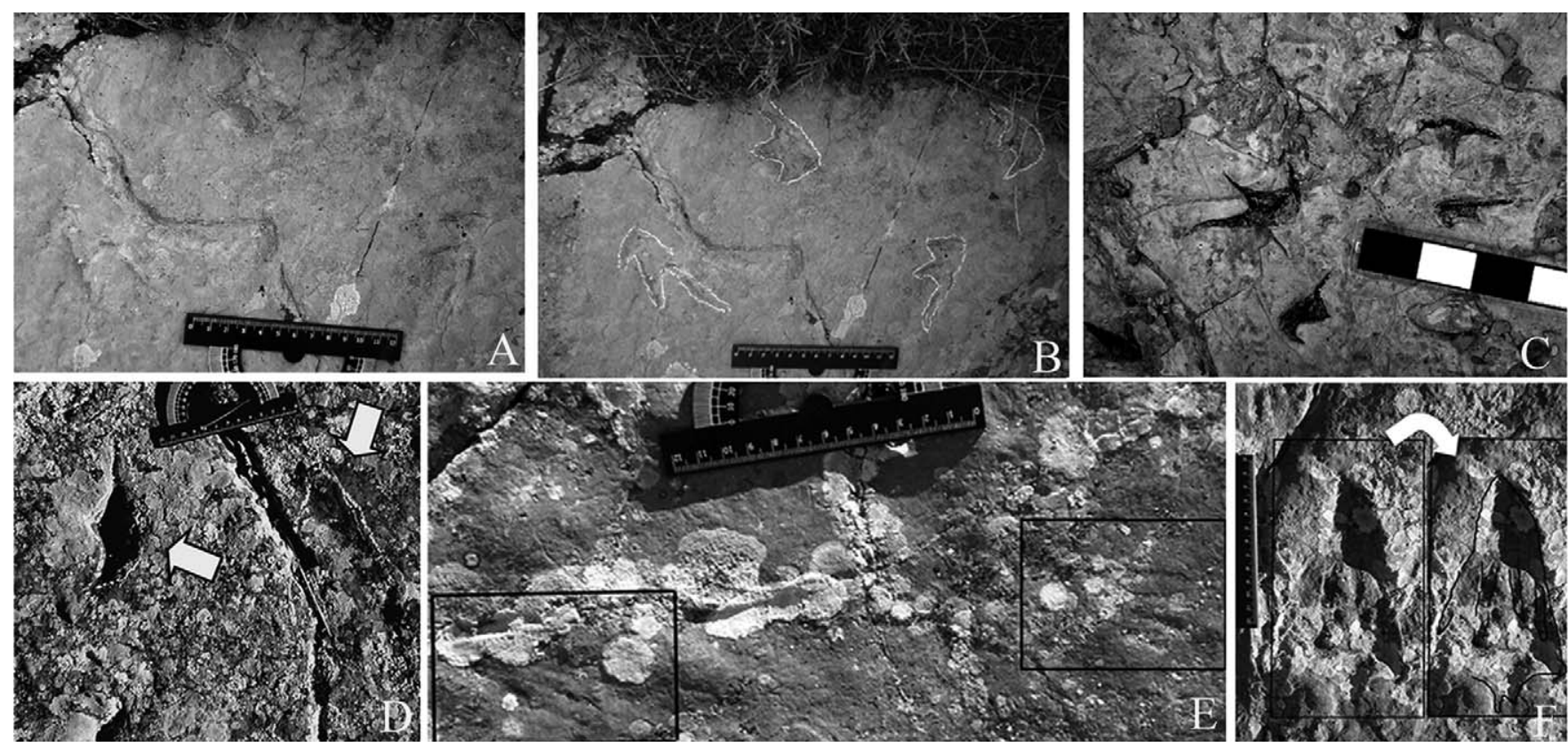

FIGURE 4. Pteraichnus tracks from outcrops in the Huérteles Alloformation, Soria Province, NE Spain. A-C, hand prints from the Valdelavilla (= Valdelalosa) outcrop. D-F, details of the poor preservation condition of the Pteraichnus palacieisaenzi tracks from the Los Tormos outcrop: a pes and manus imprint of Pteraichnus palacieisaenzi $(\mathbf{D})$, two pes imprints of smaller size $(\mathbf{E})$ and an isolated pes print that recalls the $P$. stokesi pes $(\mathbf{F})$. Scale bars equal to $12 \mathrm{~cm}$ in all the figures except in C, where every division is equal to $5 \mathrm{~cm}$. 
aichnus trackways, while their measurements show the individual prints are highly variable. Thus, different manus prints from the Valdelavilla outcrop, housed in the Museo Numantino (e.g., MNS 2002/96.30; average length/width ratio of the manus is 2.09 and the digit length ratio is 1:0.4:0.8) are similar to those considered by Pascual Arribas and Sanz Pérez (2000) as diagnostic of $P$. palacieisaenzi (where the same measurements are 2.6 and 1:1.6:3.4 respectively in MNS 2002/96.31, and 1.66 and 1:1.7:1.6 in MNS 2002/96.37). Pascual Arribas and Sanz Pérez (2000: 93) identified all the tracks from the Valdelavilla outcrop as Pteraichnus sp., arguing that they showed different measurements from the Los Tormos tracks that they identified as $P$. palacieisaenzi.

We must conclude this ichnospecies is a nomen dubium because there is no holotype or cast of the holotype in a public institution, nor is there any indication in the original paper that such a holotype exists. In any case, the photographs and measurements suggest it differs in no material way from $P$. saltwashensis.

Ichnospecies PTERAICHNUS CIDACOI Fuentes Vidarte, 2001 (nomen dubium)

Material-No type material can be traced in any museum.

Locality-Not stated.

Horizon-Huérteles Alloformation. Berriasian, Lower Cretaceous.

Description-This ichnospecies was described briefly in a onepage note in a journal with limited distribution, and the author offers no further information in later papers (Fuentes Vidarte et al., 2004a). In the illustration, the manus print has average digit length ratio of 1:1.3:2, average length of $46 \mathrm{~mm}$ and average width of $23 \mathrm{~mm}$. The pes print has an average length of $50 \mathrm{~mm}$, average width of $30 \mathrm{~mm}$ and a rounded heel (Fuentes Vidarte et al., 2004a).

Comments-This taxon is a nomen dubium because no specimen can be located in a public institution, nor has the original author made an effort to rectify the omission. According to the sketches of $P$. cidacoi by Fuentes Vidarte et al. (2004a), the manus print is similar to $P$. saltwashensis and the pes imprint is so poor it cannot readily be compared.

\section{Ichnospecies PTERAICHNUS VETUSTIOR Meijide Fuentes, 2001 (nomen dubium)}

Material-The holotype consists of manus and pes prints at the Valdelalosa I (= Valdelavilla) outcrop. The paratype consists of further manus and pes prints at the Valdelalosa II (=Valdelavilla) and Matasejún IV outcrops.

Locality-Outcrops of Valdelavilla (UTM, Universal Transverse Mercator coordinates, X 5637, Y 46470 according to Fuentes Vidarte et al., 2004a) and Matasejún (UTM X 5637, Y 46480 according to Fuentes Vidarte et al., 2004a), Soria Province, Spain.

Horizon-Huérteles Alloformation. Berriasian, Lower Cretaceous.

Description-The average digit length ratio is 1:1.6:2.6, average length of the manus print is $70 \mathrm{~mm}$ and the average width $32 \mathrm{~mm}$. The interdigital angle I-III is $88^{\circ}$. The pes print has a rounded heel, with digits of similar length, parallel and acuminated (Fig. 5) The average pes print length is $115 \mathrm{~mm}$, and average width is 90 mm (Fuentes Vidarte et al., 2004a).

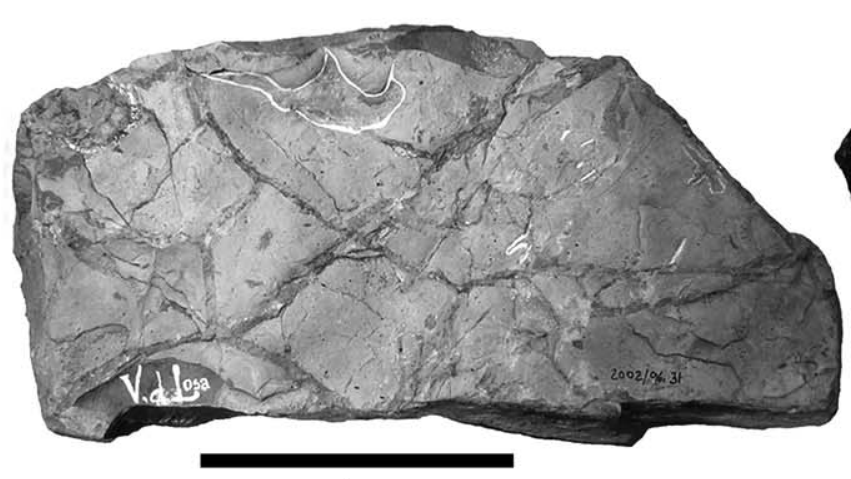

A

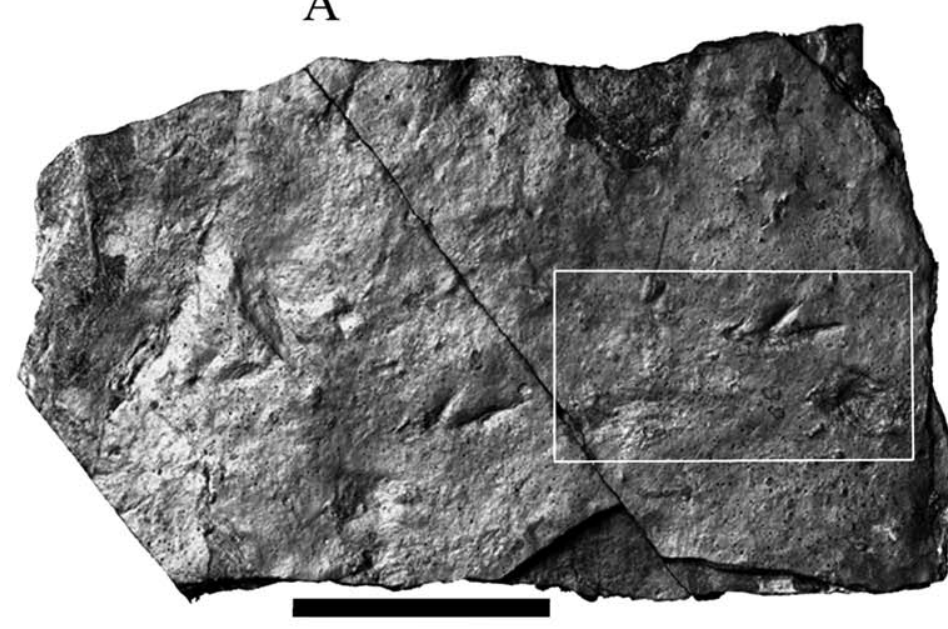

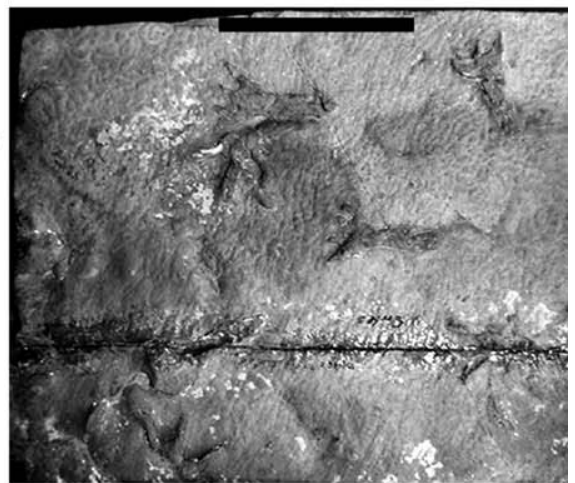

$\mathrm{C}$

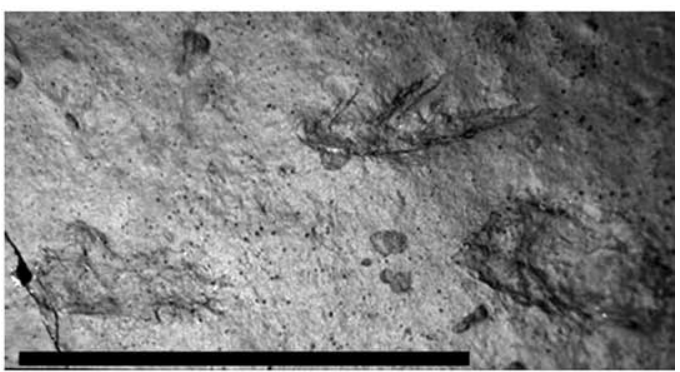

$\mathrm{D}$

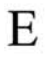

FIGURE 5. A, Shale slab with a manus imprint of Pteraichnus sp. This was identified as Pteraichnus vetustior (MNS 2002/96.31) by Fuentes Vidarte et al. (2004a), but lacks diagnostic features. B, Holotype of P. parvus (MNS 2003/92/2), modified from Fuentes Vidarte et al. (2004a). C, Detail of a manus-pes print of the holotype of P. longipodus (MNS 2003/92/5). D, E, Holotype of P. manueli (MNS 2003/92/1), general overview (D) and detail of the pes prints $(\mathbf{E})$. Scale bars equal $5 \mathrm{~cm}$. 
Comments-This ichnospecies was based on tracks in outcrop, as indicated above, and there is no type material in a public institution, so it must be considered a nomen dubium. There is a manus print housed in the MNS (MNS 2002/96.31), but it has no diagnostic features to distinguish it from other Pteraichnus manus prints from Soria Province, or from P. saltwashensis.

According to Meijide Fuentes (2001) and Meijide Fuentes et al. (2004), the digit length ratio of $P$. vetustior is 1:1.6:2.6, which is close to 1:2:3, the ratio seen in P. saltwashensis (Table 2). In the discussion, Meijide Fuentes et al. (2004) argued that an important feature of this taxon is the rounded heel shape, but this character is unclear from the illustrations.

\section{Ichnospecies PTERAICHNUS PARVUS Meijide Calvo et al., 2001}

Material-Holotype: slab MNS 2003/92/2. Paratype: footprints at the Valdelalosa III and Las Aldehuelas II outcrops. The holotype shows clear, well preserved manus and pes tracks.

Locality_Valloria outcrop (UTM X 5637, Y 46470 according to Fuentes Vidarte et al., 2004a), Soria Province, Spain.

Horizon-Huérteles Alloformation. Berriasian, Lower Cretaceous.

Description-Based on the holotype, the manus print has a digit length ratio of $1: 1.73: 3.79(=1: 2: 4)$, average length of 24.63 $\mathrm{mm}$ and average width of $12 \mathrm{~mm}$. The average manus length/ width ratio is 2.05 , and the interdigital angle values are $64^{\circ}$ (digits I-III), $58^{\circ}$ (digits II-III) and $122^{\circ}$ (digits I-III). The pes prints have an average length of $15.3 \mathrm{~mm}$, and average width of 11.43 $\mathrm{mm}$, and an average length/width ratio of 1.34. The sole imprint is substantial, representing two-thirds to three-quarters of the pes length (compared to about half in $P$. saltwashensis). The toes are slender and straight, with the second longer than the other three. All the toes have pointed ends.

Comments-This ichnospecies is valid and it is distinguished from other ichnospecies of Pteraichnus by its small size (one-fifth the typical length of a $P$. saltwashensis pes), the relatively long sole and short toes in the pes, and the relatively short manus print (length: width ratio of 2.0 compared to 2.5 in P. saltwashensis).

The digit length ratio (Table 2) was mis-measured twice by Meijide Calvo et al. (2001), who gave the ratio as 1:1:2.7 in their diagnosis (p. 487) and 1:1:1.7 in their table 1 (p. 488). The interdigital angle values gave by Meijide Calvo et al. (2001) and Fuentes Vidarte et al. (2004a) also do not correspond to those we measured (Table 2).

\section{Ichnospecies PTERAICHNUS MANUELI Meijide Calvo, 2001 (nomen dubium)}

Material-Holotype: slab MNS 2003/92/1.

Locality-Barranco de Serrantes outcrop (UTM X 5520, Y 46578 according to Fuentes Vidarte et al., 2004a), Soria Province, Spain.

Horizon-Huérteles Alloformation. Berriasian, Lower Cretaceous.

Description-In the manus print the average digit length ratio is $1: 2.68: 4.45(=1: 3: 4)$, the average length is $25 \mathrm{~mm}$ and average width $8 \mathrm{~mm}$, based on the holotype. Interdigital angle I-III is $54^{\circ}$. The pes print has a rounded heel and digits of similar length, short, slightly converging and acuminated. The average pes print length is $21 \mathrm{~mm}$, and average width is $9 \mathrm{~mm}$ (Meijide Fuentes et al., 2004).

Comments-Meijide Calvo (2001) and Meijide Fuentes et al. (2004), gave an incorrect digit length ratio of 1:2.5:3.5 for $P$. manueli. According to Meijide Calvo (2001) and Meijide Fuentes et al. (2004), the P. manueli pes print has a long plantar surface. However, similar footprints to those shown in the illustration by these authors of $P$. manueli tracks have been found at the Los Tormos locality (Fig. 3E). They are smaller than the tracks named $P$. palaciesaenzi by Pascual Arribas and Sanz Pérez (2000), and recall P. saltwashensis tracks in the general morphology of the pes and the straight toes. The length/width ratio of the pes imprint $(=2.2)$ is another feature shared by $P$. manueli and $P$. saltwashensis. $P$. manueli tracks are tiny, like those of $P$. parvus, but the proportions are different - the pes and manus are longer, so two of the diagnostic characters of $P$. parvus are not shown. The quality of the preserved pes imprints is poor, so this ichnospecies should be considered a nomen dubium until new footprints with better preservation are discovered.

\section{Ichnospecies PTERAICHNUS LONGIPODUS Fuentes Vidarte et al., 2004b}

Material-Holotype: prints of four pes and four manus in the slab MNS 2003/92/5 (Fig. 6). Paratype: prints of two manus, and incomplete pes and other unclear tracks, in the slab MNS 2003/ $92 / 6$.

Locality-Barranco de Serrantes outcrop (UTM X 5520, Y 46578 according to Fuentes Vidarte et al., 2004), Soria Province, Spain.

Horizon-Huérteles Alloformation. Berriasian, Lower Cretaceous. The horizon is not clear because neither the holotype not the paratype were found in situ (Fuentes Vidarte et al., 2004b).

Description-Based on the holotype. Manus print with an average length of $24.5 \mathrm{~mm}$, average width of $17 \mathrm{~mm}$, average manus print L/W ratio of 1.44-1.46, and average digit length ratio of 1:1.2:4.8 $(=1: 1: 5)$ showing the first digit shorter and the third longer than the others. The interdigital angle I-III is $101^{\circ}$. Pes print with an average length of $34 \mathrm{~mm}$, average width of 17.4 $\mathrm{mm}$, and average $\mathrm{L} / \mathrm{W}$ ratio of 1.95 . The interdigital angle values are $47^{\circ}$ (digits I-III), $49^{\circ}$ (digits II-III) and $96^{\circ}$ (digits I-III). The pes print shows four short digits joined at the base, creating two diverging groups. The four toe imprints are different in size, with the fourth longer than the rest. All the digits have acute nails and leave a curved distal imprint. The fifth toe is preserved in one of the footprints. The pes prints are remarkable for a
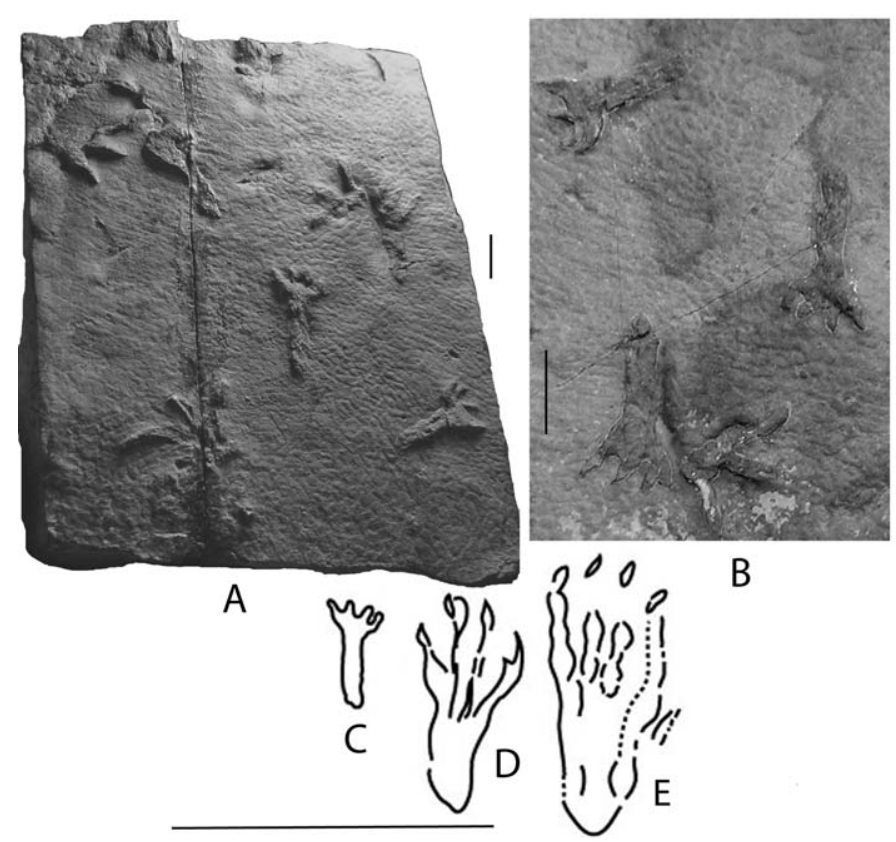

FIGURE 6. Pteraichnus longipodus, (A-C) holotype (MNS 2003/92/5), showing overview of slab (A) and detail of the pes print, without $(\mathbf{B})$ and with (C) outline added. (D) Outline of a P. saltwashensis foot print, after Stokes (1957). Scale bars equal $1 \mathrm{~cm}$. 
long narrow metatarsal imprint separated by a constriction that is more than 4.5 times the length of the longest digit imprint. There is no constriction between the metatarsal and the heel imprint.

Comments-This ichnospecies is valid, and it is distinguished from other ichnospecies of Pteraichnus by the very short manus (length/ width ratio is 1.46 , compared to 2.0 in P. parvus and 2.5 in $P$. saltwashensis), the intermediate pes (length/width ratio is 1.95, compared to 1.30 in $P$. parvus and 2.5 in P. saltwashensis). Further, the pes imprint includes a substantial metatarsal imprint, narrower than the digit imprints, and extending back for some four-fifths of the pes imprint length. The manus imprint is similar to $P$. saltwashensis.

The measurements of the pes prints could only be taken from the holotype because the paratype exhibits an incomplete pes imprint, whereas the centrally located imprint is not very clear: the supposed fifth toe imprint, observed close to the potential heel, could belong to a manus print. Based on the holotype, some of the diagnostic features mentioned by the authors of this ichnospecies should be rejected. Although many dinosaur tracks with metatarsal imprints have been described (Kuban, 1989; Lockley et al., 2003), this feature has never been reported in pterosaur tracks before. This is further morphological evidence to justify retention of this ichnospecies as valid.

\section{Ichnogenus PURBECKOPUS Delair, 1963 Ichnospecies PURBECKOPUS PENTADACTYLUS Delair, 1963}

Material-Holotype is DORCM G6664, bearing two manus, one pes, and a possible third manus imprint. Three further specimens are DORCM G9481, bearing three pes imprints, one associated with a manus imprint, DORCM G9482, bearing a solitary pes track, and OUM J21791, with poorly preserved imprints.

Locality-The holotype slab was found at Chinchen's Quarry (SY 9919 7872) on the Isle of Purbeck, Dorset. This, and the second specimen (DORCM G9481) had originally been incorporated into garden paths, and the third (DORCM G9482) was a headstone of a dog's grave (Delair, 1963; Wright et al., 1997).

Horizon-All slabs were found in the 'pink' bed of the 'roach' stone (DB 124c) in the Intermarine Member of the Middle Purbeck Limestone Formation, earliest Cretaceous (Berriasian) in age.

Description-Elongate, asymmetrical tridactyl manus imprints; elongate (approximately twice as long as wide), subtriangular, symmetrical, functionally tetradactyl, plantigrade pes imprints. The pes is $187-225 \mathrm{~mm}$ long and $98-123 \mathrm{~mm}$ wide, with a $\mathrm{L} / \mathrm{W}$ ratio of approximately 1.9. The digits of the pes are sub-equal in length and curved slightly inwards, the curvature being most pronounced in the outermost toe (digit IV). Digits II and III of the pes are slightly longer than the outer digits I and IV. Manus imprints, if present, lie outside the pes imprints, but their association is hard to determine (Wright et al., 1997).

Comments-Wright et al. (1997) argued that Purbeckopus is a valid ichnogenus, with differences in manus and pes morphology from Pteraichnus and other named tracks, especially the fatter digits and clearer phalangeal pad imprints, a view accepted by Billon-Bruyat and Mazin (2003). Its maker has been debated. Delair (1963) did not determine a track-producer, and other authors assigned the track to an unknown reptile or to a crocodilian. Wright et al. (1997) suggested that Purbeckopus was a pterosaur track, much larger than any Pteraichnus ichnospecies. Note that some tracks from France and Spain are similar in size. Billon-Bruyat and Mazin (2003) are unclear whether Purbeckopus was made by a pterosaur or some other organism.

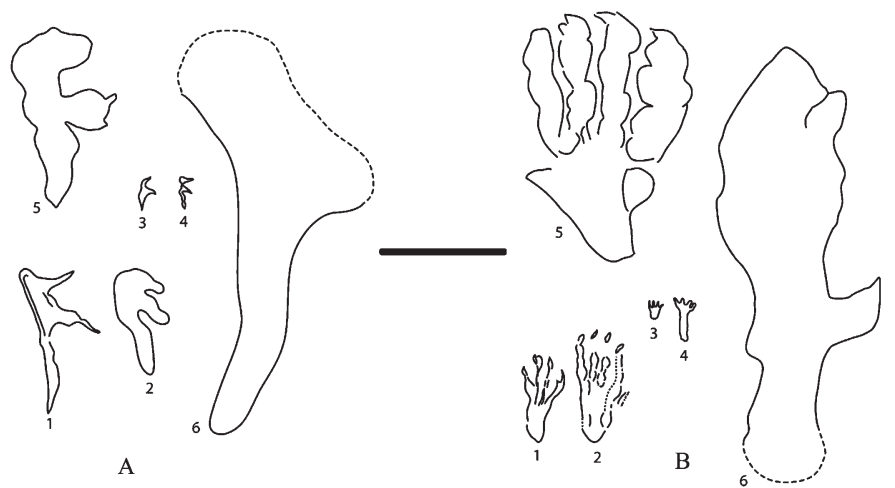

FIGURE 7. Synoptic overview of the six valid, or probably valid, pteraichnid ichnotaxa, showing manus (A) and pes (B) imprints of Pteraichnus saltwashensis (1), P. stokesi (2), P. parvus (3), P. longipodus (4), Purbeckopus pentadactylus (5), and Haenamichnus uhangriensis (6). All imprints are drawn to the same scale, and this highlights the extraordinary size and shape differences among the ichnotaxa. Scale bar equals $10 \mathrm{~cm}$.

\section{Ichnogenus HAENAMICHNUS Hwang et al., 2002 Ichnospecies HAENAMICHNUS UHANGRIENSIS Hwang et al., 2002}

Material-Holotype is a natural cast of the right manus and pes prints from site P2 (CNUPH.P2).

Locality-Southern coast of Haenam Bay, Haenam-gun, Jeollanam Province, South Korea.

Horizon-Uhangri Formation, Santonian to basal Campanian, Upper Cretaceous.

Description-The manus and pes imprints are indistinct. The manus imprints appear to be tridactyl, with short digits I and II, and a longer digit III. The manus print is about $330 \mathrm{~mm}$ long and $110 \mathrm{~mm}$ wide. The pes imprint is broadly triangular, with no separation of the digit imprints, while the heel region is narrower and apparently rounded. The separation of the digits is not evident, but the triangular shape of the anterior margins of the pes imprints suggests that digits II and III may have been the longest. The pes prints have a thick, short imprint of digit $\mathrm{V}$ and imprints of large interphalangeal pads on digits II and III. The pes print is up to $350 \mathrm{~mm}$ long and $105 \mathrm{~mm}$ wide (Hwang et al., 2002). L/W ratios for manus and pes imprints are 2.3 and 2.4 respectively.

Comments - The general shape of the presumed manus and pes prints is similar to Pteraichnus, but the imprints are so indistinct that it is hard to say more. The only distinguishing characteristic is the large size, with $H$. uhangriensis prints over three times the size of Pteraichnus prints from North America and ten times the size of some Spanish Pteraichnus. In view of the poor preservation, it is questionable whether these fossils deserve a name, but we retain the ichnogenus and ichnospecies as possibly valid (Fig. 7).

\section{PALEOECOLOGICAL AND TAPHONOMIC CONSIDERATIONS}

In ninety percent of the Cameros Basin outcrops with pterosaur footprints, manus imprints are three or four times more abundant than pes tracks. Lockley et al. (1995), Unwin (1997), and Pascual Arribas and Sanz Pérez (2000) observed the same disproportion, and they explained it by the activity of feeding in aquatic areas or by uneven body weight distribution. The disproportion may reflect aspects of the morphology of pterosaurs or of their behavior. 

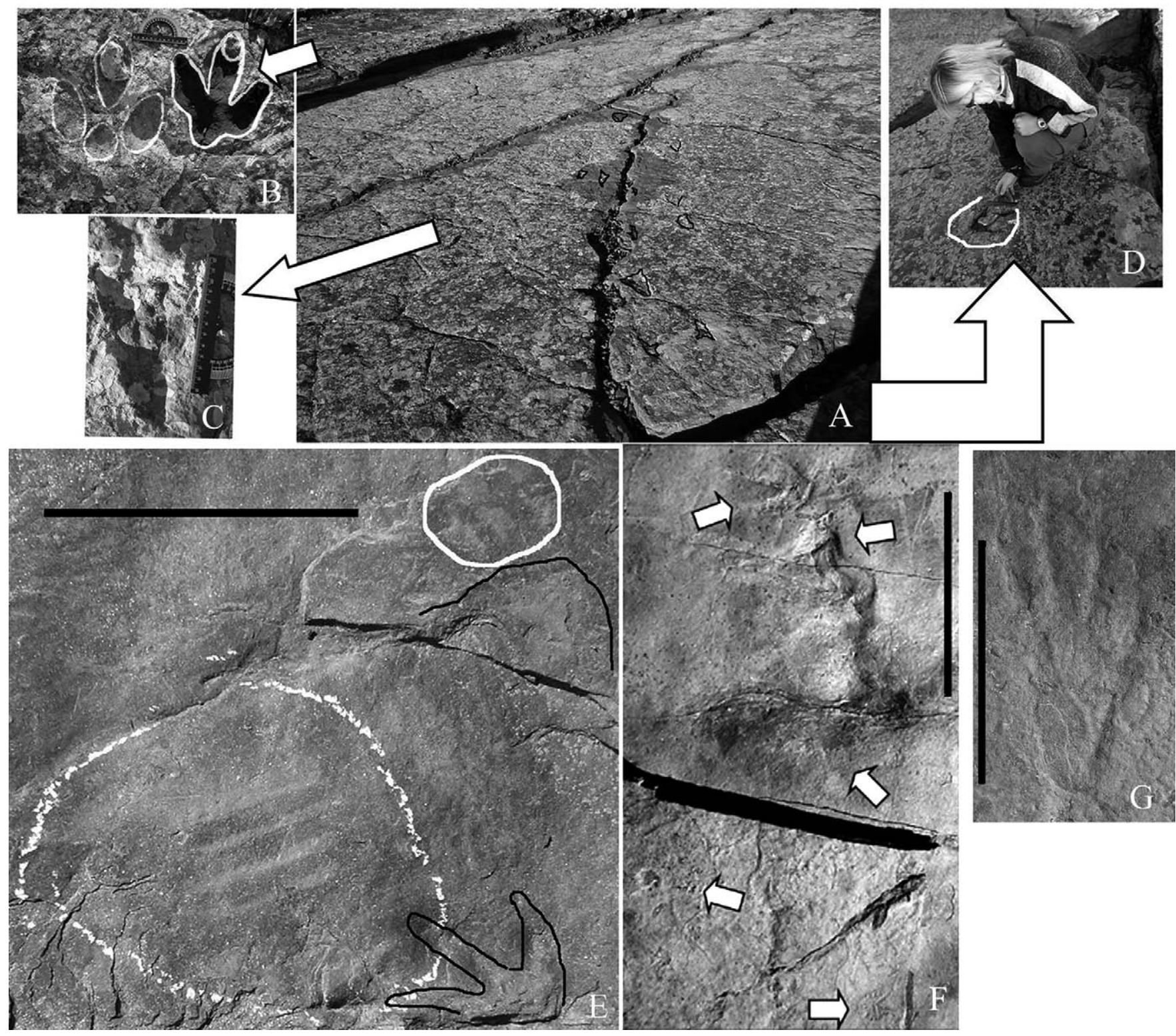

FIGURE 8. Overview of the Los Tormos outcrop (A), with a large-scale pterosaur trackway highlighted, running from bottom right to middle top of the image. Other tracks are associated with the Pteraichnus, including ornithopod pes prints (B), at a higher horizon (arrowed), and on the same layer (arrowed), a Pteraichnus pes print (C), a theropod pes print (D), turtle scratch marks, in white, and a Pteraichnus manus print, outlined in black (E), two Pteraichnus manus prints at the top (arrowed) and two plant impressions at the bottom (arrowed) (F), and well-preserved Pteraichnus pes print $(\mathbf{G})$. Scale bars are $12 \mathrm{~cm}(\mathbf{B}, \mathbf{C})$ and $5 \mathrm{~cm}(\mathbf{E}-\mathbf{G})$.

In their morphology, pterosaurs show a concentration of body mass towards the front: the wing skeleton is more substantial than the hindlimb skeleton, and the head and neck, although lightened by hollow bones and fenestrae, is large in most pterosaurs, and especially in Early Cretaceous anhanguerids and criorhynchids and Late Cretaceous pteranodontids and azhdarchids. The centre of gravity is located far forward in the centre of the trunk, essentially between the shoulder girdles (Bennett, 1997), so in normal locomotion most pterosaurs put more weight on their hands than their feet, and so made deeper manus than pes prints.

Perhaps manus prints of pterosaurs were deeper than pes prints also because of behavior. Some ichnological evidence, such as supposed beak marks associated with pterosaur tracks (e.g., Wellnhofer, 1988; Lockley et al., 1995, 1997; Unwin, 1997;
Martínez García-Ramos et al., 2002) suggests that some pterosaurs at least pecked around for food in the damp mud around lakes and seas. This behavior would involve leaning forward and perhaps impressing the manus deep into the mud, and indeed the mud might have been wet, or even covered with water if they were pecking for submerged arthropods and clams.

The opposite phenomenon may occur, where pes prints are deeper than manus prints, as for example in the case of the P. manueli holotype, perhaps with the Purbeckopus prints from England, and the $P$. saltwashensis tracks from Poland described by Pienkowski and Niedzwiedzki (2005). Perhaps some modes of locomotion, or some conditions, demanded that the animals leant back further, and perhaps adopted a more vertical stance, and so took weight from their hands. Pes-only trackways have been considered by some authors as a consequence of swimming, 
where the feet only touch the substrate as the wings float, or were used for propulsion (Lockley and Wright, 2003). It might also be that some pes-only tracks indicate bipedal walking, although that seems generally unlikely (Wellnhofer, 1988; Bennett, 1997; Unwin, 1997), or specific marks made before take off or after landing.

The Cameros Basin tracks show some evidence of ecological interactions. It is known that some spinosaur dinosaurs ate pterosaurs (Buffetaut et al., 2004), and indeed skeletal remains of pterosaurs and baryonychid spinosaurs have been reported from Cameros Basin deposits (Torcida et al., 1997; Fuentes Vidarte et al., 2001; Torcida Fernández et al., 2003). Moreover, in the Los Tormos outcrop, where theropod, turtle, pterosaur and ornithopod tracks have been observed, only the theropod and the pterosaur footprints occur at the same level (Fig. 8). Regrettably there is no evidence yet from the Cameros Basin of chewed bones or tracks that show interactions between their producers. In one case at least, there clearly was no interaction. Some turtle tracks have been observed in the same bed as pterosaur tracks at the Los Tormos outcrop (Fig. 8), but the different coloration of the sediment fill of the turtle and pterosaur prints, suggests that the turtle scratches were old when the pterosaur walked over the sediments.

\section{ACKNOWLEDGMENTS}

We thank the staff of the Museo Numantino (Soria, Castilla y León, Spain) for their help during the measurement session, and to the professional photographer A.Plaza (Museo Numantino) for some photos used in our Figure 7. Thank you also to M.L.D. Hernández for welcoming us during our stay in Soria, and to $\mathrm{S}$. Braddy (University Bristol) and A.Salvador (International Subcommission on Stratigraphic Classification) for comments on the MS. This work was supported by the 2006 Bryan Patterson Memorial Grant of the Society of Vertebrate Paleontology to BSH, the Bob Savage Fund of the University of Bristol to AP, and the Geologists' Association to AP.

\section{LITERATURE CITED}

Ambroggi, R., and A. F. Lapparent. 1954. Les empreintes de pas fossils du Maestrichtien d'Agadir. Notes du Service Geólogique du Maroc 10:43-57.

Bennett, S. C. 1997. Terrestrial locomotion of pterosaurs: A reconstruction based on Pteraichnus tracks. Journal of Vertebrate Paleontology 17:104-113.

Bertling, M., S. J. Braddy, R. G. Bromley, G. D. Demathieu, R. Mikulás, J. K. Nielsen, K. S. S. Nielsen, A. K. Rindsberg, M. Schlirf, and A. Uchman. 2006. Names for trace fossils: a uniform approach. Lethaia 39:265-285.

Billon-Bruyat, J. P., and J.-M. Mazin. 2003. The systematic problem of tetrapod ichnotaxa: the case study of Pteraichnus Stokes, 1957 (Pterosauria, Pterodactyloidea). In Buffetaut, E. (ed.), Evolution and paleobiology of pterosaurs. Geological Society of London, Special Publications 217, 315-324.

Bossi, G. E. 1998. Una alternativa en aloestratigrafía. Revista de la Asociación Argentina de Sedimentología 2:71-94.

Buffetaut, E., D. M. Martill, and F. Escuillie. 2004. Pterosaurs as part of a spinosaur diet. Nature 430:33.

Casas-Sainz, A. M., and A. Gil-Imaz. 1998. Extensional subsidence, contractional folding and thrust inversion of the eastern Cameros basin, northern Spain. Geologsiche Rundschau 86:802-818.

Delair, J. B. 1963. Notes on Purbeck fossil footprints, with descriptions of two hitherto unknown forms from Dorset, with notes on their stratigraphic distribution. Proceedings of the Dorset Natural History and Archaeological Society 42:293-322.

Fuentes Vidarte, C. 1996. Primeras huellas de aves en el Weald de Soria (España): Nuevo icnogénero, Archaeornithipus y nueva icnoespecie A. meijidei. Estudios Geológicos 52:62-75.

Fuentes Vidarte, C. 2001. A new species of Pteraichnus of the Spanish Lower Cretaceous. Pteraichnus cidacoi. Strata 11:44-46.
Fuentes Vidarte, C., M. Meijide Calvo, M. Meijide Fuentes, and F. Meijide Fuentes. 2004a. Huellas de pterosaurios en la sierra de Oncala (Soria, España). Nuevas icnospecies: Pteraichnus vetustior, Pteraichnus parvus, Pteraichnus manueli. Celtiberia 98:471-490.

Fuentes Vidarte, C., M. Meijide Calvo, F. Meijide Fuentes, and M. Meijide Fuentes. 2004b. Pteraichnus longipodus nov. icnosp. en la Sierra de Oncala (Soria, España). Studia Geologica Salmanticensia 40:103-114.

Fuentes Vidarte, C., M. Meijide Calvo, L. A. Izquierdo, D. Montero, G. Pérez, F. Torcida, V. Urién, F. Meijide Fuentes, and M. Meijide Fuentes. 2001. Restos fósiles de Baryonyx (Dinosauria, Theropoda) en el Cretácico Inferior de Salas de los Infantes (Burgos, España), pp. 349-359, in Actas de las I Jornadas Internacionales sobre Paleontología de Dinosaurios y su Entorno. Salas de los Infantes, Burgos.

Gómez-Fernández, J. C., and N. Meléndez. 1994a. Estratigrafía de la "Cuenca de Cameros" (Cordillera Ibérica Noroccidental, N de España) durante el tránsito Jurásico-Cretácico. Revista de la Sociedad Geológica de España 7:121-139.

Gómez-Fernández, J. C., and N. Meléndez. 1994b. Climatic control on Lower Cretaceous sedimentation in a playa-lake system of a tectonically active basin (Huérteles Alloformation, Eastern Cameros Basin, North-Central Spain). Journal of Paleolimnology 11: 91-108.

Guiraud, M., and M. Seguret. 1985. Releasing solitary overstep model for the Late Jurassic-Early Cretaceous (Wealdian) Soria strike-slip basin (North Spain); pp. 159-175 in K. T. Biddle and N. Christie-Blick (eds.), Strike-Slip Deformation, Basin Formation and Sedimentation. Special Publication of the Society of Economic Paleontologists and Mineralogist 37.

Haubold, H. 1971. Ichnia amphibiorum et reptiliorum fossilium. Handbuch der Paläoherpetologie 18:1-124.

Hwang, K., M. Huh, M. G. Lockley, D. M. Unwin, and J. L. Wright. 2002. New pterosaur tracks (Pteraichnidae) from the Late Cretaceous Uhangri Formation, southwestern Korea. Geological Magazine 139:421-435.

ICZN 1999. Inmternational Code of Zoological Nomenclature. 4th edition. International Trust for Zoological Nomenclature, London.

Kuban, G. J. 1989. Elongate dinosaur tracks; pp. 57-72 in D.D. Gillette, and M.G. Lockley (eds.), Dinosaur Tracks and Traces. Cambridge University Press.

Lockley, M., and J. Foster. 2003. Late Cretaceous mammal tracks from North America. Ichnos 10:269-276.

Lockley, M., M. Matsukawa, and Li Jianjun. 2003. Crouching theropods in taxonomic jungles: ichnological and ichnotaxonomic investigations of footprints with metatarsal and ischial impressions. Ichnos 10:169-177.

Lockley, M. G., T. J. Logue, J. J. Moratalla, A. P. Hunt, R. J. Schultz, and J. W. Robinson. 1995. The fossil trackway Pteraichnus is pterosaurian, not crocodilian: Implications for the global distribution of pterosaur tracks. Ichnos 4:7-20.

Lockley, M. G., M. Huh, S. K. Lim, S. Y. Yang, S. S. Chun, and D. Unwin. 1997. First report of pterosaur tracks from Asia, Chollanam Province Korea. Journal of Paleontology of the Society of Korea, Special Publication 2:17-32.

Lockley, M. G., and J. L. Wright. 2003. Pterosaur swim tracks and other ichnological evidence of behaviour and ecology; pp. 297-313 in E. Buffetaut and J.-M. Mazin (eds.), Evolution and Palaeobiology of the Pterosaurs. Geological Society of London Special Publication 217.

Martín-Closas, C., and A. Alonso Millán. 1998. Estratigrafía y bioestratigrafía (Charophyta) del Cretácico Inferior en el sector occidental de la Cuenca de Cameros (Cordillera Ibérica). Revista de la Sociedad Geológica de España 11:253-269.

Martínez García-Ramos, J. C., J. Lires, and L. Piñuela. 2002. Dinosaurios. Rutas por el Jurásico de Asturias. Grupo Zeta, Asturias 204.

Mas, J. R., A. Alonso, and J. Guimera. 1993. Evolución tectonosedimentaria de una cuenca extensional intraplaca: la cuenca finijurásica-eocretácica de Los Cameros (La Rioja-Soria). Revista de la Sociedad de Geología de España 6:129-144.

Meijide Calvo, M. 2001. Pterosaur tracks in Oncala Berriasian (Soria, Spain). New ichnospecies: Pteraichnus manueli. Strata 11:72-74.

Meijide Calvo, M., and C. Fuentes Vidarte. 2001. Huellas de pterosaurios en el Weald de Soria (España), pp. 397-406, in (C.A.S. eds.), Actas de las I Jornadas Internacionales sobre Paleontología de Dinosaurios y su Entorno. Salas de los Infantes, Burgos. 
Meijide Calvo, M., F. Meijide Fuentes, C. Fuentes Vidarte, and M. Meijide Fuentes. 2001. Huellas de pterosaurio en la Sierra de Oncala (Soria, España). Nueva icnospecies Pteraichnus parvus, pp. 397-406, in (C.A.S. eds.), Actas de las II Jornadas Internacionales sobre Paleontología de Dinosaurios y su Entorno. Salas de los Infantes, Burgos.

Meijide Fuentes, M. 2001. Pterosaur tracks in Oncala mountain range (Soria, Spain). A new ichnospecies: Pteraichnus vetustior. Strata 11:70-71.

Moratalla, J. J., J. Hernan, and S. Jimenez. 2003. Los Cayos Dinosaur Tracksite: An overview on the Lower Cretaceous ichno-diversity of the Cameros Basin (Cornago, La Rioja Province, Spain). Ichnos 10:229-240.

Muñoz, A., A. Soria, J. I. Canudo, A. M. Casas, A. Gil, and M. P. Mata. 1997. Caracterización estratigráfica y sedimentológica del Albiense marino del borde Norte de la Sierra de Cameros. Implicaciones paleogeográficas. Cuadernos de Geología Ibérica 22:139-163.

Padian, K. 1983. A functional analysis of flying and walking in pterosaurs. Paleobiology 9:218-239.

Padian, K. 2003. Pterosaur stance and gait and the interpretation of trackways. Ichnos 10:115-126.

Padian, K., and P. E. Olsen. 1984. The fossil trackway Pteraichnus: not pterosaurian, but crocodilian. Journal of Paleontology 58:178-184.

Pascual Arribas, C., and E. Sanz Pérez. 2000. Huellas de pterosaurios en el grupo Oncala (Soria, España). Pteraichnus palaciei-saenzi, nov. ichnosp. Estudios Geológicos 56:73-100.
Pienkowski, G., and G. Niedzwiedzki. 2005. Pterosaur tracks from the early Kimmeridgian intertidal deposits of Wierzbica, Poland. Geological Quarterly 49:339-346.

Stokes, W. M. L. 1957. Pterodactyl tracks from the Morrison Formation. Journal of Paleontology 31:952-954.

Tischer, G. 1965. Über die Wealden-Ablagerung und die Tektonik der östlichen Sierra der los Cameros in den nordwestlichen Iberischen Ketten (Spanien). Beihefte zum Geologischen Jahrbuch 44:123-164.

Torcida, F., C. Fuentes, L. A. Izquierdo, D. Montero, and V. Urién. 1997. Dientes de dinosaurios terópodos (cf. Baryonyx) en el Weald de Burgos (España). Studia Geológica Salmanticensia 33:59-65.

Torcida Fernández, F., L. A. Izquierdo Montero, P. Huerta Hurtado, D. Montero Huerta, and G. Pérez Martínez. 2003. Dientes de dinosaurios (Theropoda, Sauropoda), en el Cretácico Inferior de Burgos (España). pp. 335-346, in I.E.R. (eds.), Dinosaurios y otros reptiles mesozoicos en España. Instituto de Estudios Riojanos, Logroño.

Unwin, D. M. 1997. Pterosaur tracks and the terrestrial ability of pterosaurs. Lethaia 29:373-386.

Wellnhofer, P. 1988. Terrestrial locomotion in pterosaurs. Historical Biology 1:3-16.

Wright, J. L., D. M. Unwin, M. G. Lockley, and E. C. Rainforth. 1997. Pterosaur tracks from the Purbeck Limestones Formation of Dorset, England. Proceedings of the Geologists' Association 108:39-48.

Submitted March 29, 2008; accepted July 13, 2008. 